\title{
DEVELOPMENT AND ANALYSIS OF DIAGNOSTIC CRITERIA FOR CREATION OF AN AUTOMATED COMPUTER SOFTWARE FOR PREDICTING THE COURSE AND INDIVIDUALIZING THE TREATMENT OF PATIENTS WITH ODONTOGENIC MAXILLARY SINUSITIS
}

DOI: 10.36740/WLek202004127

\author{
Olexsandr O. Voloshan, Sergey M. Grigorov, Dmytro S. Demyanyk \\ KHARKIV NATIONAL MEDICAL UNIVERSITY, KHARKIV, UKRAINE
}

\begin{abstract}
The aim of our study was to create a database of the most informative diagnostic criteria for predicting the treatment results for various odontogenic maxillary sinusitis (OMS) forms using automated computer software.

Materials and methods: In order to select and assess the most informative diagnostic criteria for predicting the treatment results for various 0MS forms, the total of 9 subject matter experts (SME) were included into the problem commission on the specialty "Dentistry".

Results: After calculating the data obtained according to the method of Yana V. Nosova, the working group experts'level of competency was $M=0.90$. This confirmed the group's qualification, which further led to the approval of scoring coefficients, depending on the degree of a particular index importance. The basic and minor parameters in the subjective, objective, introscopic and laboratory data of OMS patients were identified.

Conclusions: The developed database of diagnostic criteria has formed the basis of an automated computer software for predicting the course and individualizing the patients' treatment in odontogenic maxillary sinusitis.
\end{abstract}

KEY WORDS: odontogenic maxillary sinusitis, medical expert systems, computer-aided systems, diagnosis and treatment, computer-based disease prediction

Wiad Lek. 2020;73(4):767-772

\section{INTRODUCTION}

One of the results of the intellectual technology development in the modern world was the emergence of the term "artificial intelligence". Such information activities include expert systems, which are high-level software systems that accumulate experts' knowledge in a narrow subject matter for assistance and consultation of less qualified staff. The expert system includes data and knowledge bases, a developed software system for their processing $[1,2,3,4]$.

The first known diagnostic algorithms emerged in the late 1950s, using the scoring principle of calculation [5]. The known method for quantitative assessment of a specific symptom and a diagnostic criterion is used to create expert systems by qualified specialists down to our days. Thus, one of the most common ways to determine weight factors is the expert evaluation method (attribution of points) $[6,7,8]$.

Thus, these systems can be used in medicine and, particularly, in dentistry $[9,10,11,12]$. The expert system can be used for many medical and diagnostic purposes: to solve problems of diagnostics, to establish the diagnosis, to appoint medical measures, to predict the course of the disease and to prevent threatening complications [13]. Our sphere of interest is the treatment of patients with various diseases of the maxillofacial area, so it remains relevant to improve the diagnosis and treatment of patients with odontogenic maxillary sinusitis (OMS), as one of the most common pathologies.

The share of odontogenic etiology diseases amounts up to $25 \%$ of the total number of references from patients with sinusitis $[14,15]$. The clinical diversity of OMS course variants drive the need to determine the most informative diagnostic criteria to create a computer-based prognostic software to improve patient outcomes in this pathology. The literature review has revealed the absence of such an expert system in the treatment of patients with OMS, which determines the relevance of the study and gives grounds for its further development.

\section{THE AIM}

The aim of our study was to create a database of the most informative diagnostic criteria for predicting the treatment results for various OMS forms using automated computer software.

\section{MATERIALS AND METHODS}

To select and assess the most informative diagnostic criteria for predicting the results of treatment in various OMS 
forms, the total of 9 subject matter dentistry experts were included into the problem commission on the specialty "Dentistry".

According to current data [3], an important aspect of this study, to which attention has been paid, is to determine the level of the working group experts competence $(\mathrm{M})$ to obtain reliable baseline data (which meets the following condition: $0.67 \leq M \leq 1.00$ ).

The $\mathrm{M}$ value was calculated according to the formula:

$$
M=\frac{1}{m} \cdot \sum_{j=1}^{m} K_{j},
$$

where $K_{j}$-competence level of j- expert, $m$ - number of experts in the working group.

We also assessed the competence level $\left(K_{j}\right)$ directly of each expert $(j=1 . m)$ who was included into the working group using the following formula:

$$
K_{j}=\frac{1}{5} \sum_{i=1}^{5} K_{i j}
$$

In assessing each expert's level of competence, five generalized indices were selected $\mathrm{K}_{\mathrm{ij}}\left(0 \leq \mathrm{K}_{\mathrm{ijj}} \leq 1\right)$, where:

$K_{1 j}$-takes into account professional qualifications, job seniority and work experience;

$K_{2 j}$ - takes into account the level of awareness in the field of scientific publications;

$K_{3 j}$ - takes into account striving for professional growth, ability to work in a team, as well as discipline and orderliness based on self-esteem;

$K_{4 j}$ - takes into account the expert's personal qualities assessed by his expert colleagues;

$K_{5 j}$ - takes into account the level of the expert's actions coordination with the members of the formed working group when performing the test task.

The studies were performed in accordance with the basic provisions of the "Rules of Ethical Principles for Medical Research Involving Human Subjects", approved by the Declaration of Helsinki (1964-2013), ICH GCP (1996), EEC Directive No. 609 (dated 24.11.1986), Ministry of Health of Ukraine Decrees No. 690 dated September 23, 2009; No. 944 dated December 14, 2009; No. 616 dated August 3, 2012.

\section{RESULTS AND DISCUSSION}

After calculating the data obtained by means of the above methodology, the competence level of the working group experts was $M=0.90$. This result was consistent with the research of Yana V. Nosova (2018) and confirmed the qualification of the formed group, which has further led to the approval of scoring coefficients, depending on the importance degree of a particular index. Scores of 0 to 9 for each assessment criterion were suggested for experts' consideration. Subjective, objective data of introscopic and laboratory studies were subject to calculation.

The baseline data for the study were obtained from the case histories analysis of patients undergoing inpatient treatment at the Department of Head and Neck Surgery of
KNP KhOR "OKL" (regional clinic hospital), the clinical base of the Surgical Dentistry and Maxillofacial Surgery Department at Kharkiv National Medical University.

The subjective data base was mainly based on anamnestic data and complaints presented by patients with various OMS forms. The most significant indices corresponded to the higher number of points (from 5 to 9 points), for example, they were: the presence of a connection between the oral cavity and the nose (oroantral communication of different genesis - 7 points); the presence of liquid, food ingress into the nasal cavity - 7 points; face asymmetry, soft tissue swelling of more than 2 anatomical areas - 9 points; constant nasal congestion on the relevant side and multiple discharge -5 and 6 points, respectively. Experts considered the group of less significant criteria in the point ratio (from 1 to 5 points), such as: edema and the presence of excretions through the fistula in the gum area of the causative tooth ( 1 and 3 points); pain when biting on a tooth with moderate intensity (1 point); feeling of heaviness in the head area (1 point); body temperature with no more than $38.0 \mathrm{C}$ (2 points) (table I).

The objectification and scoring of the patient's local status permitted to distinguish the basic and minor parameters that influenced the correct diagnosis and determination of the disease stage course. We have referred the following parameters to the main precipitating factors: sharply laboured nasal respiration on the affected side (5 points); swelling of the face in more than 2 anatomical areas ( 9 points); purulent or purulent-hemorrhagic nature of discharge in abundance (7 points); positive nasal-oral, oral-nasal tests ( 7 points); the presence of purulent exudate in the area of the perforation hole (7 points); positive symptom of soft tissue fluctuation (5 points). Examples of minor diagnostic criteria were: the presence of Dupuytren's symptom in the area of the alveolar process in the projection of the causative or extracted tooth; evaluation of the mucous membrane condition in the area of the causative or extracted tooth; results of percussion and palpation in the area of the causative tooth, etc. (table II)

Much attention was paid to identifying and distributing the most informative criteria in introscopic studies. We used the following radiographic methods: intra-oral spot-film dental radiography, X-ray radiography of the paranasal sinuses (PNS), panoramic radiography. However, the assessment of specific radiographic parameters was carried out using the most up-to-date additional method of studying the dental-maxillary system - 3-D computed tomography, as an informative detailed study of pathological changes in bone structures, the maxillary sinus mucous membrane (MS) and the presence of various foreign objects (filling material, etc.) in it. A pathognomic parameter with a high level of reliability was the transparency degree assessment of the MS.

Totally veiled sinus was assessed at 9 points, $2 / 3$ changes - at 6 points. The most burdening etiologic factors were determined to be the following: - MS fistula (9 points), MS perforation ( 7 points) and root-end cyst (7 points); and the 
Table I. Patient's subjective data characteristic

\begin{tabular}{|c|c|c|}
\hline Data characteristic & Criteria & Points \\
\hline 1 & 2 & 3 \\
\hline \multirow{9}{*}{ 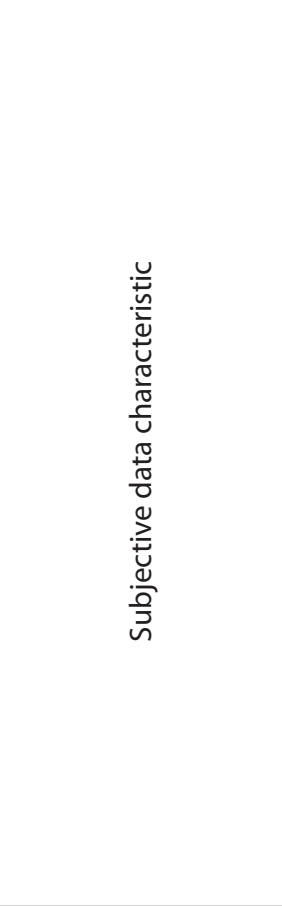 } & Pain in the area of the causative / extracted tooth & $\begin{array}{l}\text { Yes- } 1 \\
\text { No- } 0 \\
\end{array}$ \\
\hline & Pain when biting on the tooth & $\begin{array}{l}\text { Yes- } 1 \\
\text { No- } 0 \\
\end{array}$ \\
\hline & Palpation pain & $\begin{array}{l}\text { Yes- } 1 \\
\text { No- } 0 \\
\end{array}$ \\
\hline & The presence of discharge through a fistula in the gum area & $\begin{array}{l}\text { Yes- } 3 \\
\text { No- } 0 \\
\end{array}$ \\
\hline & Gum swelling in the area of the causative / extracted tooth & $\begin{array}{l}\text { Yes- } 1 \\
\text { No- } 0 \\
\end{array}$ \\
\hline & The presence of a communication between the oral cavity and the nose & $\begin{array}{l}\text { Yes- } 7 \\
\text { No- } 0 \\
\end{array}$ \\
\hline & $\begin{array}{c}\text { Pain irradiation into: } \\
\text { ear } \\
\text { temple } \\
\text { eye } \\
\end{array}$ & $\frac{\text { Each area }-1}{\underline{\text { No }-0}}$ \\
\hline & $\begin{array}{l}\text { Pain intensity: } \\
\text { moderate } \\
\text { intense }\end{array}$ & $\begin{array}{l}\text { moderate- } 1 \\
\text { intense-3 } \\
\text { absent - } 0 \\
\end{array}$ \\
\hline & Feeling of heaviness in the head area & $\begin{array}{l}\text { Yes- } 1 \\
\text { No- } 0 \\
\end{array}$ \\
\hline \multirow{7}{*}{ 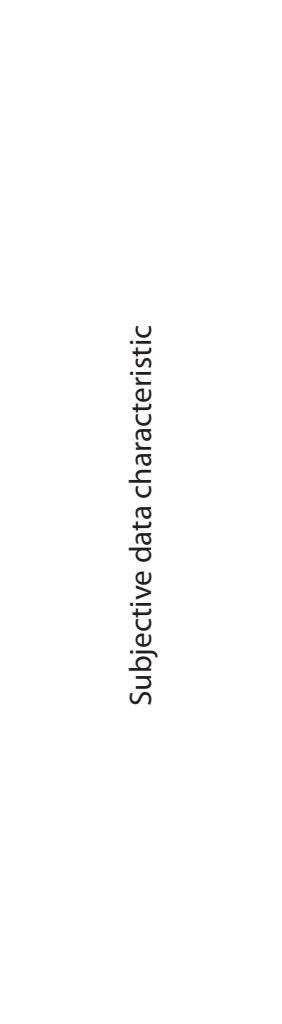 } & $\begin{array}{c}\text { Facial asymmetry, soft tissue swelling in the area of: } \\
\text { cheeks } \\
\text { infra-orbital region } \\
\text { more than } 2 \text { anatomical areas }\end{array}$ & $\begin{array}{l}\text { cheek-3 } \\
\text { infra-orbital - } 3 \\
\text { More than 2-9 }\end{array}$ \\
\hline & $\begin{array}{l}\text { No nasal congestion on the appropriate side is noted } \\
\text { periodic nasal congestion on the appropriate side } \\
\text { constant nasal congestion on the appropriate side }\end{array}$ & $\begin{array}{l}0 \\
3 \\
5\end{array}$ \\
\hline & $\begin{array}{c}\text { Nose discharge: } \\
\text { No } \\
\text { primordial } \\
\text { repeatedly }\end{array}$ & $\underline{0}$ \\
\hline & $\begin{array}{l}\text { The presence of food, fluid ingress into the nasal cavity: } \\
\qquad \text { Yes } \\
\text { No }\end{array}$ & $\begin{array}{l}\text { Yes- } 7 \\
\text { No- } 0 \\
\end{array}$ \\
\hline & $\begin{array}{c}\text { Body temperature } \\
36.6 \\
37.0-37.5 \\
37.6-38.0 \\
\text { Over } 38.0 \\
\end{array}$ & $\begin{array}{l}\underline{0} \\
\frac{1}{2} \\
\underline{3} \\
\underline{3}\end{array}$ \\
\hline & $\begin{array}{l}\text { General malaise, weakness: } \\
\text { Yes } \\
\text { No }\end{array}$ & $\begin{array}{l}\text { Yes- } 1 \\
\text { No- } 0 \\
\end{array}$ \\
\hline & $\begin{array}{c}\text { Concomitant chronic diseases: } \\
\text { Yes } \\
\text { No }\end{array}$ & $\begin{array}{l}\text { Yes- } 1 \\
\text { No- } 0\end{array}$ \\
\hline
\end{tabular}

number of causative teeth exceeding 3 and being subject to extraction was estimated at 9 points. The presence of polyposis - the altered MS mucous membrane was assigned 7 points. Equally significant was the assessment of foreign bodies presence in maxillary cavities of various genesis: tooth fragments and dental implant (6 points), filling material (9 points). As to the scoring ratio, the parameter revealing the spread of the pathological process into the area of the middle meatus was referred to secondary ones by the experts ( 5 points), etc.

To the study and calculation of laboratory parameters, we included the data analysis of pathogenic microflora 
Table II. Patient's objective data characteristic

\begin{tabular}{|c|c|c|}
\hline Data characteristic & Criteria & Points \\
\hline 1 & 2 & 3 \\
\hline \multirow{14}{*}{ 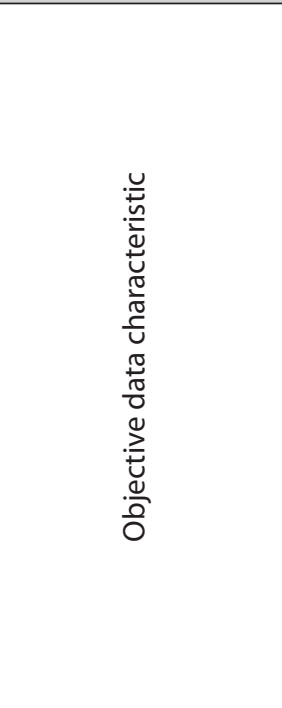 } & \multicolumn{2}{|l|}{ Palpation pain of the mucous membrane in the causative / extracted tooth area: } \\
\hline & Yes & 1 \\
\hline & No & $\underline{0}$ \\
\hline & \multicolumn{2}{|l|}{ Painful result of the causative tooth (s) percussion: } \\
\hline & \multirow{2}{*}{$\begin{array}{c}\text { No } \\
\text { vertical }\end{array}$} & $\underline{0}$ \\
\hline & & 1 \\
\hline & horizontal & $\underline{1}$ \\
\hline & \multicolumn{2}{|l|}{$\begin{array}{l}\text { Swelling in the area of the mucous membrane of the causative / extracted tooth } \\
\text { (Dupuytren's symptom): }\end{array}$} \\
\hline & 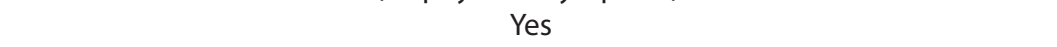 & Yes-1 \\
\hline & No & $\underline{\underline{\text { No }-0}}$ \\
\hline & $\begin{array}{l}\text { Condition of the mucous membrane in the area of the causative / extracted tooth: } \\
\text { satisfactory - no edema and hyperemia of the mucous membrane } \\
\text { unsatisfactory - there is edema and hyperemia of the mucous membrane }\end{array}$ & $\underline{0}$ \\
\hline & \multicolumn{2}{|l|}{ Fetor discharge } \\
\hline & Yes & $\underline{0}$ \\
\hline & No & $\underline{3}$ \\
\hline \multirow{29}{*}{ 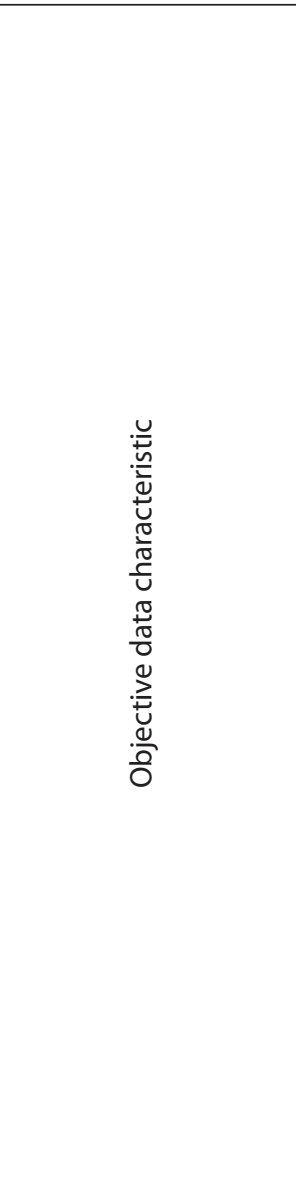 } & \multicolumn{2}{|l|}{ Symptom of fluctuation in soft tissues: } \\
\hline & Yes & $\underline{5}$ \\
\hline & No & $\underline{0}$ \\
\hline & \multicolumn{2}{|l|}{ Discharge amount } \\
\hline & moderate & $\underline{3}$ \\
\hline & \multicolumn{2}{|l|}{ profuse } \\
\hline & \\
\hline & unilateral & $\underline{3}$ \\
\hline & & $\underline{6}$ \\
\hline & \multirow{2}{*}{\multicolumn{2}{|c|}{$\begin{array}{l}\text { Nasal respiration: } \\
\text { free }\end{array}$}} \\
\hline & & $\underline{0}$ \\
\hline & & $\underline{\overline{3}}$ \\
\hline & \multicolumn{2}{|l|}{ sharply laboured } \\
\hline & \\
\hline & positive & $\underline{7}$ \\
\hline & negative & $\underline{0}$ \\
\hline & \\
\hline & \multicolumn{2}{|l|}{$\begin{array}{l}\text { Discharge nature: } \\
\text { no }\end{array}$} \\
\hline & \multirow{2}{*}{$\begin{array}{l}\text { serous } \\
\text { serous-hemorrhagic }\end{array}$} & $\underline{2}$ \\
\hline & & $\underline{2}$ \\
\hline & purulent & $\underline{\bar{z}}$ \\
\hline & purulent-hemorrhagic & $\underline{z}$ \\
\hline & \multicolumn{2}{|l|}{ Face configuration is impaired by swelling in the area: } \\
\hline & the buccal area & $\underline{3}$ \\
\hline & the infra-orbital region & $\underline{3}$ \\
\hline & more than 2 anatomic areas & $\overline{\underline{9}}$ \\
\hline & \multicolumn{2}{|l|}{ Presence of purulent exudate in the perforation hole: } \\
\hline & Yes & $\underline{7}$ \\
\hline & No & $\underline{0}$ \\
\hline
\end{tabular}

bacteriological studies of the following strains in the nasal cavity and pharynx: Staphylococcus spp., Streptococcus spp., Enterococcus., Enterobactericae spp., Micrococcus sppis, M., Cateria spp., H. Influenze. The presence of 2 or more monocultures was assessed at 6 and 9 points, respectively (table III).

\section{CONCLUSIONS}

The findings from these studies have led to forming a reliable database of objective and most informative diagnostic criteria. With the help of a qualified expert group, points were assigned to certain criteria, depending on the degree of pathological changes manifestation. After calculating all the parameters by 
Table III. Specification of additional methods (introscopic) to study patient's data and laboratory parameters

\begin{tabular}{|c|c|c|}
\hline Data characteristic & Criteria & Points \\
\hline 1 & 2 & 3 \\
\hline \multirow{9}{*}{ 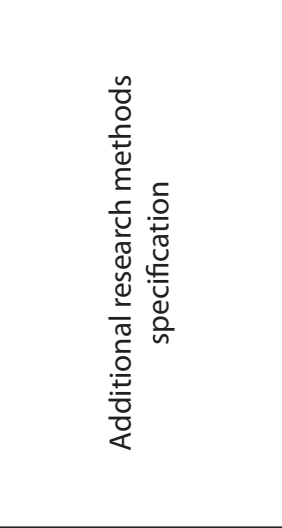 } & $\begin{array}{c}\text { Presence and size of the perforation hole in the area of the extracted, } \\
\text { potentially extracted tooth (s): }\end{array}$ & \\
\hline & $0.5-1.0 \mathrm{~cm}$ & 1 \\
\hline & $1.0-1.5 \mathrm{~cm}$ & 3 \\
\hline & more than $1.5 \mathrm{~cm}$ & 5 \\
\hline & \multicolumn{2}{|l|}{ Number of causative teeth: } \\
\hline & 1 tooth & 3 \\
\hline & 2 teeth & 6 \\
\hline & 3 teeth and more & 9 \\
\hline & $\begin{array}{l}\text { Odontogenic maxillary sinusitis: with a well-pronounced bone septum between } \\
\text { the focus of odontogenic infection and the maxillary sinus. } \\
\text { Odontogenic maxillary sinusitis: with no distinct bone septum between the } \\
\text { focus of odontogenic infection and the maxillary sinus. }\end{array}$ & 1 \\
\hline \multirow{21}{*}{ 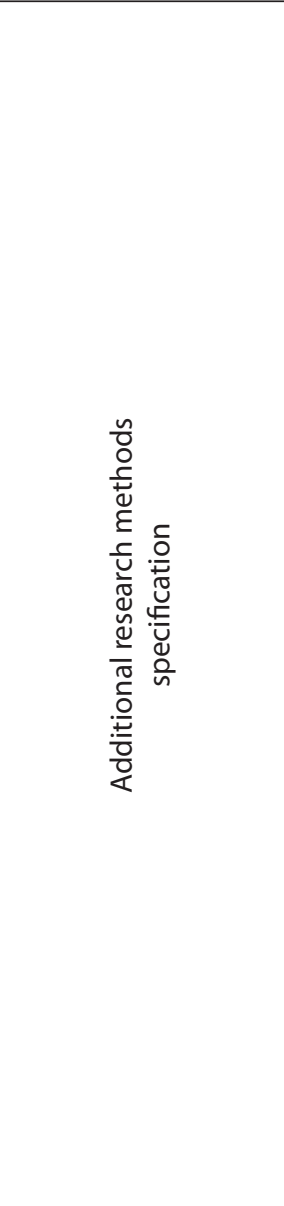 } & \multicolumn{2}{|l|}{ Process extension to the middle meatus (meatus nasi medius): } \\
\hline & covers & $\underline{5}$ \\
\hline & does not cover & $\underline{\overline{0}}$ \\
\hline & $\begin{array}{l}\text { Changes in the sinus mucosa: } \\
\text { parietal thickening of the sinus mucosa } \\
\text { retention cyst of the mucous membrane } \\
\text { polypous -changed } \mathrm{m} / \mathrm{m}\end{array}$ & $\begin{array}{l}\underline{3} \\
\underline{5} \\
\underline{7}\end{array}$ \\
\hline & Etiological odontogenic factor. & \\
\hline & acute & 3 \\
\hline & chronic & 5 \\
\hline & exacerbation of chronic & 5 \\
\hline & cyst granuloma & 5 \\
\hline & root end cyst & 7 \\
\hline & perforation of maxillary sinus & 7 \\
\hline & fistula of maxillary sinus & 9 \\
\hline & $\begin{array}{l}\text { Condition of other airway sinuses: } \\
\text { norm } \\
\text { presence of ethmoiditis } \\
\text { presence of frontitis } \\
\text { presence of sphenoiditis } \\
\text { presence of hemisinusitis }\end{array}$ & $\begin{array}{l}\frac{0}{3} \\
\frac{3}{3} \\
\underline{3} \\
\underline{9}\end{array}$ \\
\hline & \multicolumn{2}{|l|}{ Transparency changes degree in the maxillary sinus: } \\
\hline & $1 / 3-$ & $\underline{3}$ \\
\hline & $2 / 3-$ & $\underline{6}$ \\
\hline & $3 / 3-$ & $\underline{9}$ \\
\hline & \multicolumn{2}{|l|}{ Presence of a foreign body in the maxillary sinus: } \\
\hline & tooth fragments & $\underline{6}$ \\
\hline & dental implant & $\underline{6}$ \\
\hline & filling material & $\underline{\overline{9}}$ \\
\hline \multirow{4}{*}{ 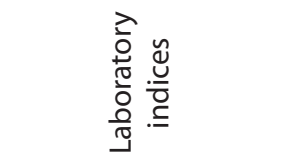 } & \multicolumn{2}{|l|}{ Result of the microflora microbiological study of the nose and oropharynx: } \\
\hline & 1 strain & 3 \\
\hline & 2 strains & 6 \\
\hline & 2 and more strains & 9 \\
\hline
\end{tabular}

means of an expert system, they will be automatically converted into points, which will permit to establish the previous (computer) diagnosis, to identify risk groups, to establish prognosis for possible complications, and to provide recommendations for optimized comprehensive treatment of OMS patients.

Thus, the above mentioned database of diagnostic criteria has formed the basis of an automated computer software for predicting the course and individualization of patients' treatment in odontogenic maxillary sinusitis.

\section{REFERENCES}

1. Jackson P. Introduction to expert systems. 3rd ed. Expert Systems and Artificial Intelligence Boston. Addison-Wesley Longman Publishing Co. 1998; 2-12. 
2. Prodeus A.M. Ekspertni systemy v medytsyni .Medichni informacijni sistemi. [Expert Systems in Medicine. Medical information systems]. Zaporizhzhia: ZDIA Publishing House, 2014; 10-22. (In Ukrainian).

3. Belle A., Thiagarajan R., Reza Soroushmehr S. M. et al. Big Data Analytics in Healthcare. Biomed Res Int. 2015;370194. doi: 10.1155/2015/370194.

4. Obermeyer Z., Phil M., Ezekiel J. Emanuel. Predicting the Future Big Data, Machine Learning and Clinical Medicine 2016 ; 375(13): 1216-1219. doi: 10.1056/NEJMp1606181

5. Belle A., Kon M., Najarian K. Biomedical Informatics for Computer-Aided Decision Support Systems: A Survey. The Scientific World Journal. 2013; 769639.doi: 10.1155/2013/769639

6. Nosova Y. K voprosu o formalizatsii diagnostiki obonyatelnyih narusheniy. [To the question of the formalization of the diagnosis of olfactory disorders]. Bionics of intelligence. Kharkov. KNURE, 2017; 89:183 - 187 (In Russian).

7. Nosova Y., Shevchenko S., Khudaieva S. Calculation of weight indicators of the importance of using odorivectors for the purpose of formalizing olfactometry diagnosis. International Academy Journal. Web of Scholar, 2018; 25 (1): $20-22$.

8. Nosova Y., Avrunyn 0., Shushlyapyna N. Opredelenie nadezhnosti olfaktometricheskih izmereniy [Determination of reliability of alpha metric measurements].XVI International Science. Conference" ${ }^{\text {"Physical }}$ Processes" 2017; 79-80. (In Russian).

9. Nikol's'kyy Y., Shcherbyna Y., Yakimenko R. Dereva pryiniattia rishen ta yikhnie zastosuvannia dlia prohnozuvannia diahnozu u medytsyni. [Tree of decision making and their application for prediction of a diagnosis in medicine] .Visnyk of Lviv University. Series of Applied Mathematics, Computer Science. 2003; 15-27 (In Ukranian).

10. Groselj D. Computer Aided Diagnostic System in Dentistry in D. Groselj ,M. Malus, I. Grabec. Medical Informatics Europe. P. Kokol et al. (Eds.) IOS Press, 1999; 639- 644.

11. López-López J., Jose M. Álvarez-López, Jané-Salas E. Computer-aided system for morphometric mandibular index computation (Using dental panoramic radiographs). Med Oral Patol Oral Cir Bucal. 2012; 17(4): e624-e632. doi: 10.4317/medoral.17637

12. Lei Chen, Tao Huang, Chuan Lu et al. Machine Learning and Network Methods for Biology and Medicine. Comput Math Methods Med.2015:915124. doi: 10.1155/2015/915124

13. Ohashi Y., Arij Y., Katsumata A. Utilization of computer-aided detection system in diagnosing unilateral maxillary sinusitis on panoramic radiographs. Dentomaxillofac Radiol. 2016; 45(3): 20150419. doi: 10.1259/dmfr.20150419
14. Mikhaylov Y.U. Nekotoryie teoreticheskie i metodologicheskie problemyi sovremennoy rinologii. [Some Theoretical and Methodological Problems of Modern Rhinology]. Military Medical Journal. 2006; 6: 52-56. (In Russian).

15. Kim Y., Lee K.J., Sunwoo L., et al. Deep Learning in Diagnosis of Maxillary Sinusitis Using Conventional Radiography. Invest Radiol. 2019;54(1):715. doi: 10.1097/RLI.0000000000000503.

The article is a fragment of the initiative research project implemented at the Department of Dental and Maxillo - Facial Surgery of Kharkiv National Medical University "Nature, structure and treatment of major diseases", the implementation period was 2016-2018, state registration No. $0116 U 004975$.

\section{ORCID and contributionship:}

Olexsandr O. Voloshan - 0000-0002-7079-1878 ${ }^{A, B, D}$

Sergey M. Grigorov - 0000-0001-9527-8408 E,F

Dmytro S. Demyanyk - 0000-0003-2347-4754 ${ }^{\mathrm{C}}$

\section{Conflict of interest:}

The Authors declare no conflict of interest.

\section{CORRESPONDING AUTHOR Olexsandr 0. Voloshan}

Kharkiv National Medical University, Kharkiv, Ukraine tel: +380934016532

e-mail: alexsurgery1990@gmail.com

Received: 01.07.2019

Accepted: 07.02 .2020

A - Work concept and design, B - Data collection and analysis, C - Responsibility for statistical analysis, D-Writing the article, E-Critical review, F - Final approval of the article 